World Inequality Lab - Working Paper N²021/13

\title{
Towards equity and sustainability? China's pension system reform moves center stage
}

\author{
Li Yang
}

April 2021

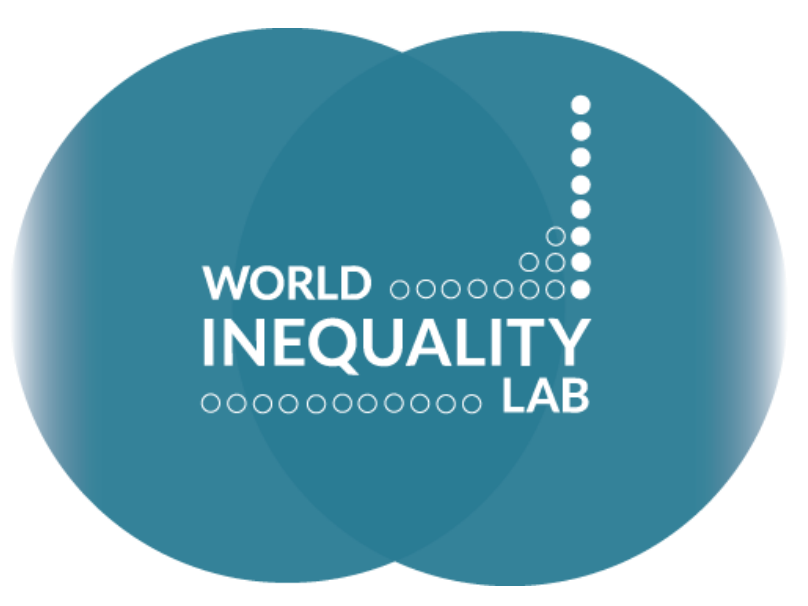

WID.WORLD

THE SOURCE FOR

GLOBAL INEQUALITY DATA 


\title{
Towards equity and sustainability? China's pension system reform moves center stage
}

\author{
Li Yang*
}

\begin{abstract}
In this paper I review the latest development of China's public pension system. Last several decades saw China's tremendous achievement in various public pension reforms. Especially since the 11th Five-Year Plan (2006-2010), reform has accelerated. By 2019, the public pension system in China has covered almost one billion adults, which makes it the biggest pension system in the world. Together with the expansion of Dibao (Basic living allowance) and the eradication of poverty, the development of pension system has become the top agenda in current policy making of the Chinese government. Yet, challenges exist: unequal distribution of pension resource and the long-run unsustainability of the pension system are waiting to be addressed with increasing urgence. Although potential countermeasures, both based on international experience and with Chinese feature, has been proposed and piloted in both regional and national level, there are incremental pressure for further reforming the system. In the latest Five-Year Plan (2021-2015), the government has vowed to construct a unified, equitable, and sustainable pension system with full coverage. This is a very challenging yet exciting goal to achieve not only for the policy makers, but also for academic researchers and general public.
\end{abstract}

*Li Yang: Paris School of Economics and INSEAD, 48 Boulevard Jourdan, 75014 Paris, France (email: li.yang@psemail.eu). I am grateful for comments to Mikko Huotari. 


\section{Introduction: China's pivotal reform of pension system}

For international observers on China, the most frequently discussed topics are the magnificent economic growth and human rights related issues. However, they often overlook a critical topic for both China's economic development, social stability as well as billions of Chinese citizens' welfare, the pivotal Chinese public pension reform. Since China embarked on full-fledged reforms and market opening in 1978, the government has been pushing ahead with social security reforms as a key component of its economic reforms. While the momentous pension reform in 1980s and 1990s was initiated as a major vehicle to improve the productivity of state-owned enterprises, reforms since the 11th Five-Year Plan (2006-2010) have mainly been driven by the unprecedented demographic change of an aging society. According to the latest report on China's population aging by the China Development Research Foundation ${ }^{1}$, the number of Chinese aged 65 and above will reach 420 million in 2035, and 500 million in 2050. On the verge of such profound demographic changes, the Chinese government has set the establishment of a unified, equitable, and sustainable pension system with universal coverage on its key agenda. $^{2}$ Until today, it has made remarkable achievements towards to this goal. By 2019 the public pension system in China has covered almost one billion adults, which makes it the biggest pension system in the world. Yet, challenges exist: unequal distribution of pension resources and the long-run unsustainability of the pension system are waiting to be addressed with increasing urgence. How to solve these two issues will be instrumental for China's further development trajectory, both economically and politically. To date, Chinese government has piloted in both regional and national level several potential countermeasures, both based on international experience and with Chinese feature. Yet, incremental pressure for further reforming the system remains.

\section{The moving frontiers of China's public pension system reform.}

China embarked on its journey to a modern pension system by initiating an enterprise-sponsored scheme with very low coverage in the early 1950s. Ever since several reforms marked key turning points of the development of the public pension system. We divide them in to two phases, according to the driving forces: reforms before 2000, which were taken as a vehicle to improve productivity of the State-Owned Enterprises (SOEs) and reforms afterwards, which were solely driven by the rapid demographic transformation.

\footnotetext{
1 "China Development Report 2020: Aging Population: China's Development Trends and Policy Options"

2 See China's 11th-14th Five-Year Plan.
} 


\section{Market driven reform: establishment of Basic Old Age Insurance}

In the early 1950s, like many predominantly agrarian newly independent nations, China initiated an enterprise-sponsored public pension scheme, in which pensions were restricted to wage earners, notably urban industrial workers and government employees. ${ }^{3}$ Together with other state welfare systems, such a public pension scheme provided the foundation for a degree of social security for urban and state sector workers rarely found in developing countries. ${ }^{4}$ However, the rural population - then more than $80-90 \%$ of total population, was excluded in the state welfare system. In 1989, only $7 \%$ of adult population in China were covered by the public pension scheme.

As the marketization of the economy saw a reduced role and decreasing profitability of state-owned enterprises, enterprise-based pension system became increasingly untenable. A key subsequent reform in 1986 introduced a defined benefit pension system whose administration was assigned to municipalities, but the whole system remained financed by enterprises. Yet, this new system soon came under financial distress, mostly due to firms evading their obligations to pay pension contributions.

Since the 1990s, China has put in great effort in expanding and improving the social security system in urban areas. ${ }^{5}$ In 1997, the State Council decided to establish a two-tiered social security system (plus a voluntary third tier). ${ }^{6}$ The first tier is a standard Pay-as-you-go pension system ${ }^{7}$ financed by employers, with resource pooling at the local government level. ${ }^{8}$ The second tier is a notional individual account financed by employees' contributions. ${ }^{9}$ This new system is called Basic Old Age Insurance (BOAI, in Chinese: 基本养老保险), which is managed by a new Ministry - the Ministry of Labor and Social Security, established in 1998. Public (civil service) employees are covered by the Public Employee

\footnotetext{
${ }^{3}$ In 1951, "labor insurance" was introduced as an unfunded, employer-sponsored pension program that covered employees of State-Owned Enterprises (SOEs) and collectively owned enterprises, while public (civil service) employees were covered a separate pension system, the Public Employee Pension (PEP).

${ }^{4}$ Leung and Nann (1995, p. 61) overstate the case when they suggest that "The work-based welfare system provides a level of coverage that would be considered comprehensive and generous in comparison with the most advanced welfare states in the west."

5 "The circular on deepen enterprise employee pension insurance system reform" (State Council Document [1995] 6);

6 "A Decision on Establishing a Unified Basic Pension System for Enterprise Workers" (State Council Document [1997]26).

State pension systems that are funded by contributions from current workers (rather than by individual past contributions from current beneficiaries)

${ }^{8}$ Funded by $17 \%$ wage taxes paid by enterprises, guarantees a replacement rate of $20 \%$ of local average wage for retirees with a minimum of 15 years of contribution.

${ }^{9}$ Financed by a contribution of $3 \%$ and $8 \%$ wage taxes paid by enterprises and workers, respectively. In 2005 , a new

reform was implemented, individual accounts are now funded by the wage taxes of $8 \%$ paid by workers only.
} 
Pension (PEP, in Chinese: 公务员养老金).

\section{Ticking clock of aging population tsunami: acceleration of reforms since 2000s}

Since China officially became an ageing nation in $2000^{10}$, the country's ageing process has only picked up speed. Urged on by such a foreseeable aging population tsunami, China deepened the pension reform and dramatically expanded the pension coverage since the turn of the century. BOAI coverage was expanded from state-owned enterprises and urban collective enterprises to foreign-invested enterprises, and private-owned enterprises. ${ }^{11}$ In 2005 , the coverage further extended to urban individual industrial and commercial households and persons in flexible employment. ${ }^{12}$ Yet the new pension system is still largely inadequate.

In contrast to the development of the pension system in urban areas, the public pension system has left a void in rural areas, where the rural residents still mostly rely on family for old age support. ${ }^{13}$ To address this issue, China has launched a new round of pension reforms, which is characterized by universal coverage of public pension system. In 2006, the Sixth Plenary Session of the 16th Central Committee of the Communist Party of China proposed to establish and improve a social security system covering both urban and rural residents by 2020 .

Largely in line with this plan, a sequence of policy measures between 2009 and 2015 was critical for establishing the current form of the Chinese public pension system (see also Table 1 and Graph 1):

- the New Rural Social Pension Scheme (NRSPS, in Chinese：新型农村社会养老保险) scheme was first established to cover rural residents ${ }^{14}$ in 2009.

- the Social Insurance Law enacted in 2011 stipulates that rural migrant workers are to be given the same treatment as that given to urban workers.

- In 2012, another new scheme was established for urban residents without work, the Urban Residents Pension Scheme (URPS, in Chinese：城镇居民社会养老保险), which was merged with NRSPS into Urban and Rural Residents Pension Scheme (URRPS, in Chinese: 城乡居民 社会养老保险) in 2014 .

- Additionally, in 2015, the Public Employee Pension (PEP) was merged into Basic Old Age

${ }^{10} \mathrm{UN}$ definition of aging society: society with $10 \%$ population aged 60 or above.

11 "Interim Regulations on the Collection of Social Insurance Premiums" (State Council Order [1999] 259)

12 "Decision of the State Council on Improving the Basic Pension Insurance System for Enterprise Employees" (State Council Document [2005] 38)

${ }^{13}$ The 2010 census data show 5 percent of rural elders mainly lived on pensions, and close to 60 percent of them lived on private transfers.

${ }^{14} \mathrm{Lu}$ and Stepan (2016) provides a detailed policy review of the development of NRSPS. 
Insurance (BOAI).

Under URRPS, pension benefit consists of a pension from a personal account calculated based on contributions and a basic pension financed by local and central government. In particular, for the participants who were older than 60 years old by 2014, basic pension is provided independently of contribution history. The initial value of the basic pension is 55 yuan per month (about 7.3 Euro), which can be supplemented by local governments at their discretion from their own revenues. ${ }^{15}$

Table 1. Evolution of China's public pension system since 1997

\begin{tabular}{|c|c|c|c|c|c|c|}
\hline \multirow[b]{2}{*}{ Year } & \multicolumn{3}{|c|}{ Urban } & Rural & Urban & Rural \\
\hline & $\begin{array}{l}\text { Urban Employee (non } \\
\text { government agencies } \\
\text { and institutions) }\end{array}$ & $\begin{array}{c}\text { Staff of government } \\
\text { agencies and } \\
\text { institutions }\end{array}$ & $\begin{array}{l}\text { Urban non-working } \\
\text { residents }\end{array}$ & Rural residents & \multicolumn{2}{|c|}{ Population share (\%) } \\
\hline 1997 & \multirow{4}{*}{ BOAI } & \multirow{4}{*}{ EPE } & & \multirow{3}{*}{ NRSPS } & $32 \%$ & $68 \%$ \\
\hline 2009 & & & & & $48 \%$ & $52 \%$ \\
\hline 2011 & & & URPS & & $51 \%$ & $49 \%$ \\
\hline 2014 & & & \multirow{2}{*}{\multicolumn{2}{|c|}{ URRPS (Voluntary) }} & $55 \%$ & $45 \%$ \\
\hline 2015 & \multicolumn{2}{|c|}{ BOAI (Mandatory) } & & & $56 \%$ & $44 \%$ \\
\hline
\end{tabular}

Notes: BOAI: Basic Old Age Insurance; EPE: Public Employee Pension; URPS: Urban Resident Pension Scheme; NRSPS: New Rural Resident Pension Scheme; URRPS: Rural and Urban Resident Pension Scheme.

\section{Graph 1: Timeline of key reforms on public pension system}

\footnotetext{
${ }^{15}$ For example, in Shanghai the value of the basic pension is 1100 RMB per month in 2020, while in Shang Dong, it is 142 RMB per month.
} 


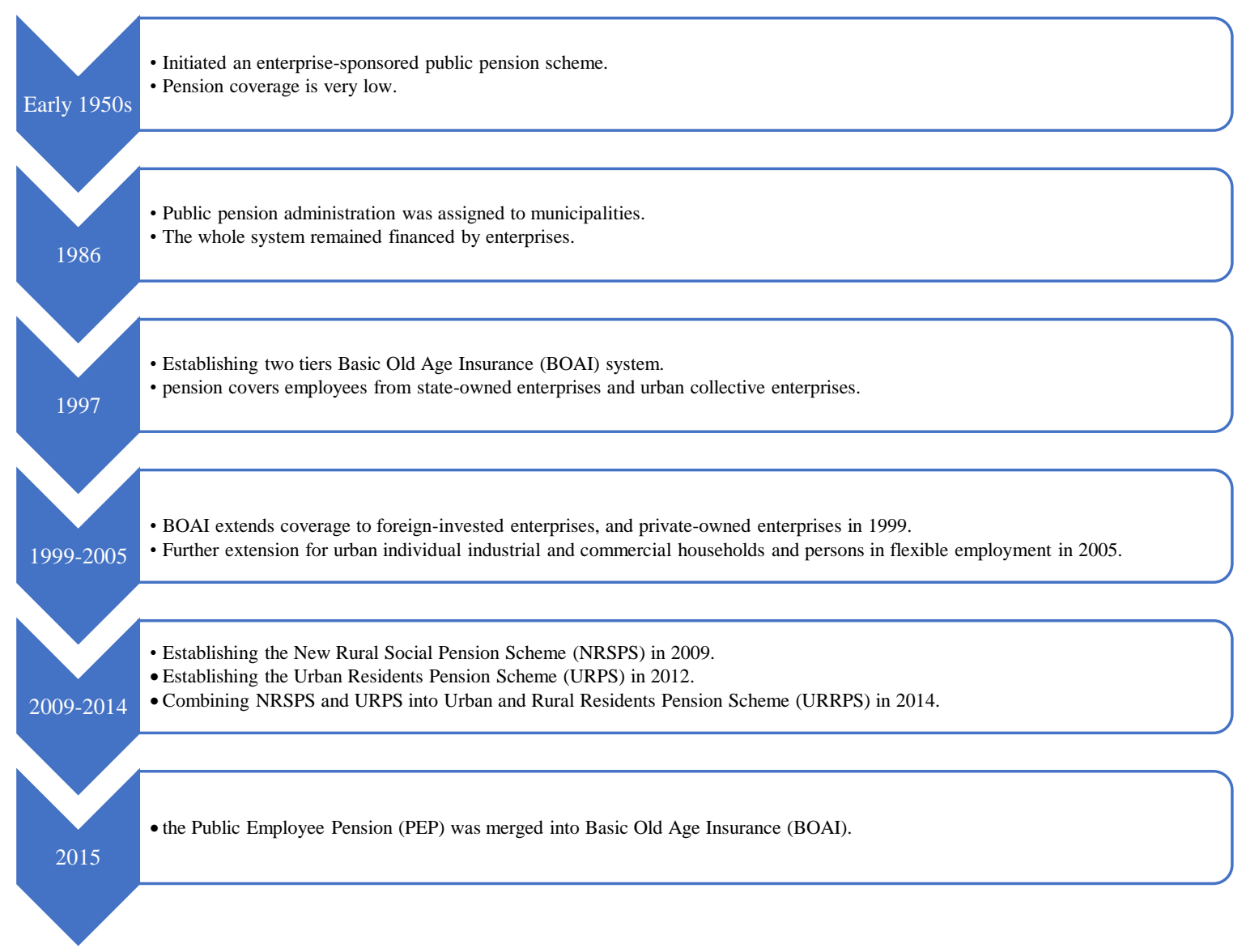

\section{Full coverage and more benefits - but challenges remain}

Driven by the strong policy of public pension reform, the coverage as well as the level of the benefit of the pension has expanded tremendously in the last three decades. Since 1989, the enrollment of BOAI in urban areas grew from merely 50 million to 450 million, while the average annual benefits almost decupled from 4250 RMB to 39990 RMB (2019 RMB) (Figures 1 and 3). Subsequence to the latest round of reform since 2000, the coverage rate of BOAI rose from $40 \%$ in 2003 to $60 \%$ in 10 years (Figure 2). The development of URRPS ${ }^{16}$ in urban and rural areas is even more astonishing: the enrollment of URRPS sprang from less than 60 million in 2008 to more than 480 million in 4 years ${ }^{17}$, in 2019, the total enrollment or URRPS reached to 530 million (Figure 1). By the end of the decade, BOAI and URRPS together covered $84 \%$ of rural and urban adult population. For its unprecedented extension of pensions, health insurance and other forms of social protection, the International Social

${ }^{16}$ Before 2014, the enrollment of URRPS is equal to total enrollment of NRSPS and URPS.

${ }^{17}$ Before 2011, data only covers NRSPS, since URPS was not initiated yet. 
Security Association, the world's leading international organization for social security institutions, government departments and agencies, gave its prestigious Award for Outstanding Achievement in Social Security ${ }^{18}$ to the Chinese government in 2016.

Figure 1. Enrollment and recipients in China's pension system (million persons)

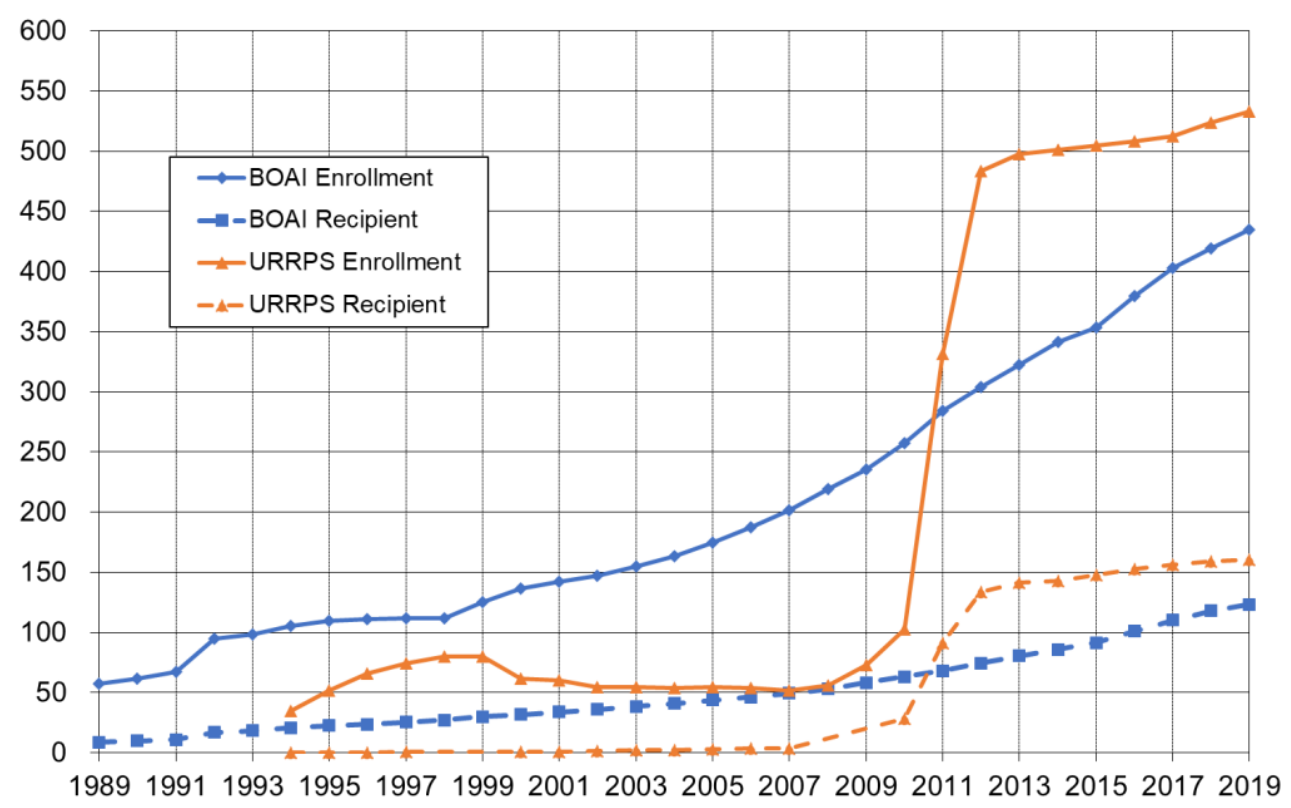

Notes: Enrollment includes both pension contributors and pension recipients. Recipients are the people who receive benefit from pension funds. Data is from National Bureau of Statistics of China (http://www.stats.gov.cn/tjsj/)

Figure 2. Coverage of China's pension system (in \%)

\footnotetext{
${ }^{18}$ The award, bestowed by the ISSA every three years, offers worldwide recognition of a country's political commitment and long-term results in the field of social security.
} 


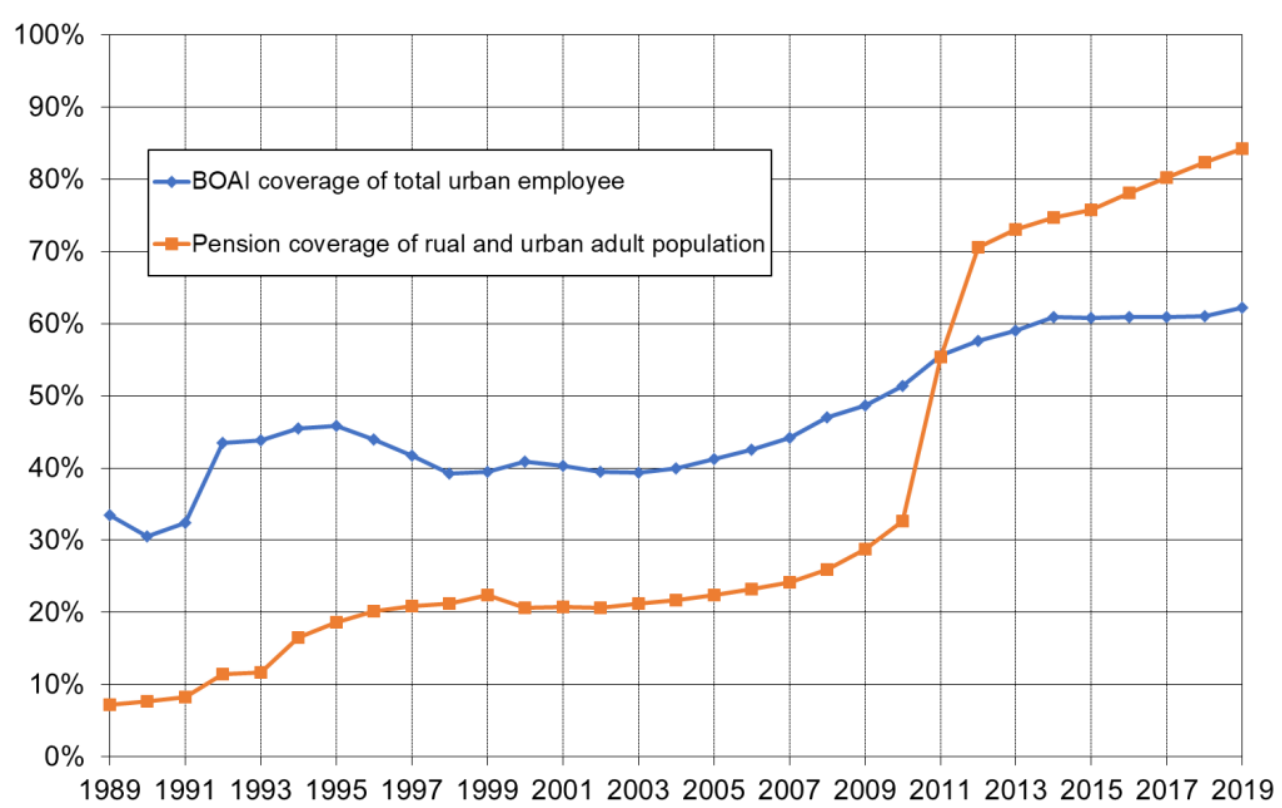

Notes: Urban employee includes urban enterprise employee and non-enterprise employee (i.e., urban individual industrial and commercial households and persons in flexible employment). Adult population is defined as population older or equal to 16 years old. Statistics are estimated based on data published by National Bureau of Statistics of China (http://www.stats.gov.cn/tjsj/).

Figure 3. Average annual pension benefit level (2019 yuan)

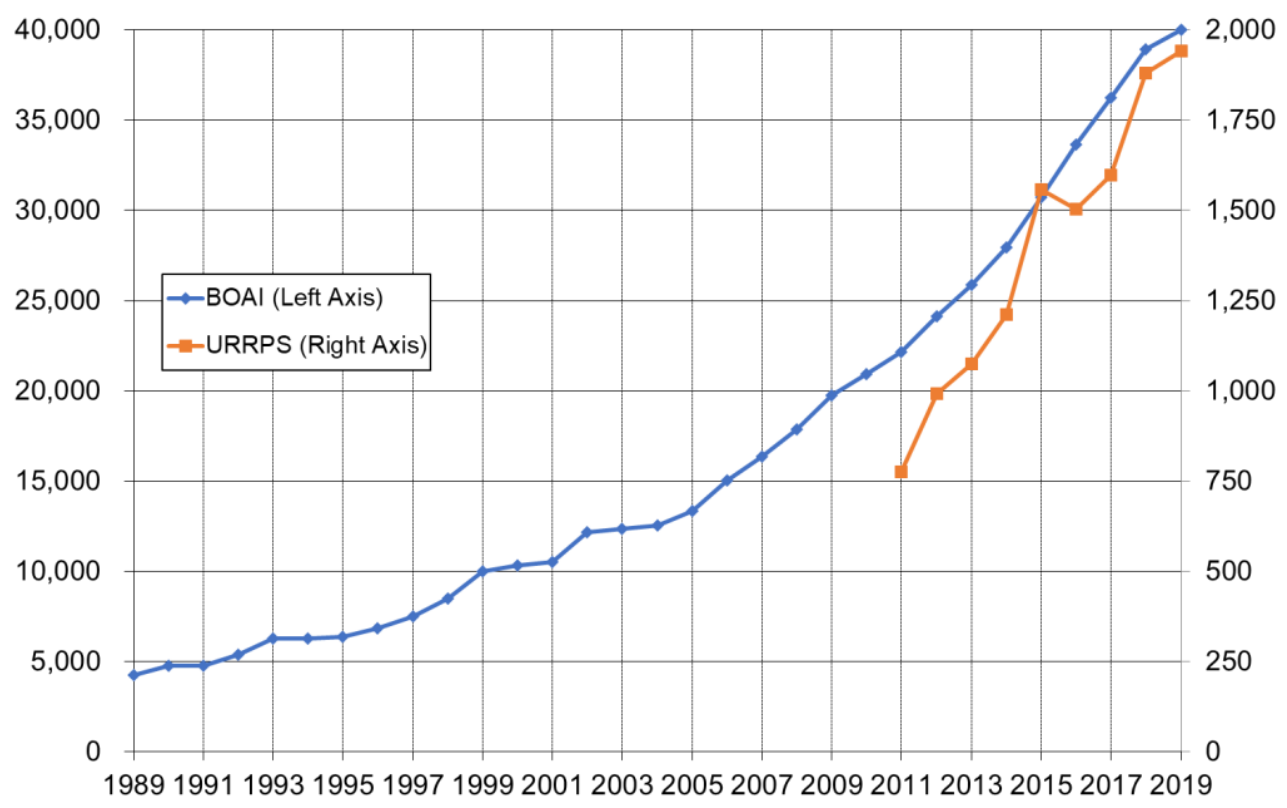

Notes: Average annual pension is equal to total pension expenditure divided by number of pension Recipients. Statistics are estimated based on data published by National Bureau of Statistics of China (http://www.stats.gov.cn/tjsj/).

Despite impressive progress of public pension scheme in achieving near-universal coverage, the system is still fragmented, unequal, and inadequate: 


\section{- Substantial gap between BOAI and URRPS:}

- Unequal benefits: in 2019, the annual average pension benefit for urban employees is about 40,000 RMB, contrasting to merely 2000 RMB in URRPS, which is less than half of the BOAI pension benefit (in real terms) in 1989.

- Difference in the replacement ratio ${ }^{19}$ : the replacement ratio in BOAI is more than 3 times higher than in RUUPS (Figure 4).

- Unequal subsidization: Although URRPS is heavily subsidized by the government (in 2018, 72\% of URRPS income is subsidized vs. 14\% for BOAI), in absolute numbers the annual subsidy amount for every BOAI pension recipient is $4500 \mathrm{RMB}$, which is substantially higher than the subsidy amount for every URRPS pension recipient of $1750 \mathrm{RMB}$.

- Given this circumstance, till today in rural China adult children remain the most important source of elderly care and financial support.

- Unsustainability: In 2035, the number of Chinese aged 60 and above will reach 420 million, accounting $30 \%$ of total population. Without further pension reform, the accumulated balance of BOAI funds will be exhausted by then. ${ }^{20}$

Figure 4. Replacement ratio of China's pension system (\%)

\footnotetext{
${ }^{19}$ A Replacement Ratio is a person's gross income after retirement, divided by his or her gross income before retirement. In this paper, we estimate BOAI replacement ratio using average pension benefit divided by average wage income of urban employees. Similarly, URRPS rural replacement ratio is estimated using average pension benefit divided by average disposable income of rural residents.

${ }^{20}$ See "China Pension Actuarial Report 2019 -2050" by Chinese Academy of Social Sciences (CASS)
} 


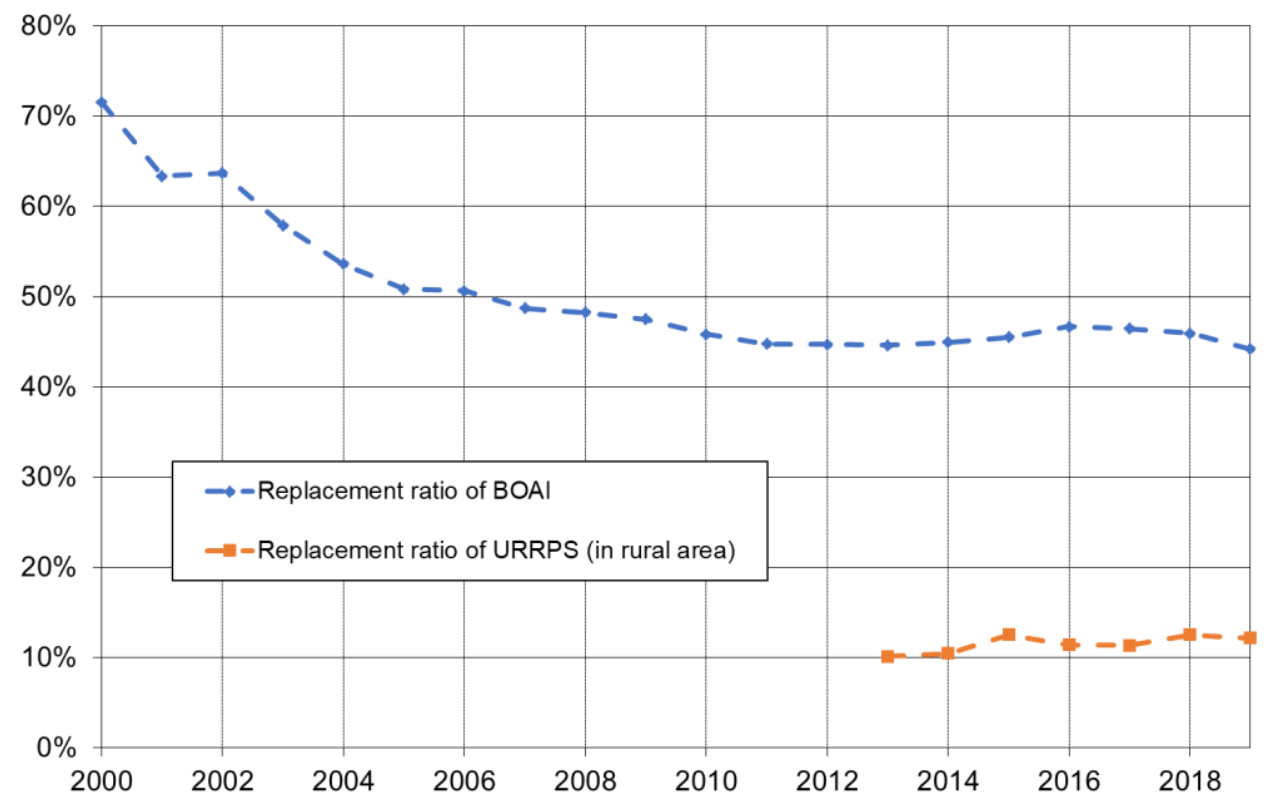

Notes: we estimate BOAI replacement ratio using average pension benefit divided by average wage income of urban employees. Similarly, URRPS rural replacement ratio is estimated using average pension benefit divided by average disposable income of rural residents. Statistics are estimated based on data published by National Bureau of Statistics of China (http://www.stats.gov.cn/tjsj/).

In the medium-term, tackling two specific challenges, redistributive effects of the pension system (inequality) and long-term sustainability will be critical for not only economic development but also social stability of China.

\section{Pension reforms could increase inequality}

The above-described characteristics, and the extreme gap between different public pension schemes in particular, point to a larger challenge facing Chinese policymakers: the redistributive and inequality effects of government social security transfers.

\section{The challenge}

Findings in the research literature on this issue are unsurprising, yet striking. First, the overall social security transfer is regressive in China. Especially, formal sector pensions (BOAI) are the most inequality enhancing factor; whereas Dibao (Basic living allowance, in Chinese: 低保) and rural pension benefits have equalizing effects on the income distribution in China. However, the extent of its regressivity decreased over time, suggesting an equity-oriented policy direction echoed by several 
recent government initiatives to support rural residents, migrants and the urban poor. ${ }^{21}$ When focusing on elderly households the results are even stronger, the distribution of pension incomes is highly unequal, with a Gini coefficient of 0.74 in 2013. Similarly, public pension income has been the largest source of income inequality and contributed to more than half of total income inequality. Thus, merely increasing the existing pensioners' benefits at the same rate, as current urban biased pension benefit indexation policies, will most likely increase income inequality among the elderly population. ${ }^{22}$ When we look into urban and rural areas respectively, the redistributive nature of social benefits appears to be a twosided story (as many other dimensions of Chinese society): urban social benefits were much more generous and overall progressive, while rural social benefits were minimal and consistently regressive. Despite the public pension in urban areas is overall progressive, it is regressive within certain age cohorts. $^{23}$

The regressive nature of China's public pension system roots in its still fragmented pension scheme design. Instead of focusing on providing basic economic security to retirees, current pension scheme over-emphasizes on pension contribution. ${ }^{24}$ Indeed, the current fragmented pension scheme design might be a reasonable choice to expand the pension coverage in the short amount of time, however one has to admit that such contribution-based pension scheme will naturally introduce more inequality, which contradicts the initial goal of social welfare transfer. It is worth noting that such fragmented pension design has much deeper implications than just increasing economic inequality. In particular, Baeten (2013) et al. finds pensions at older ages may be one of the most important policy levers for reducing health disparities in China.

Possible solutions: non-contributory social pensions and the integration of urban-rural pension systems

To address the above issue, several possible reform directions were proposed in the public debates, including the introduction of a nationwide non-contributory based social pension and full integration of rural and urban pension systems.

International experience suggests that full pension coverage is very difficult to achieve at the level of the individual in rural and informal sector schemes based on approaches that require contributions, even

${ }^{21}$ See. Cai and Yue, 2020, Wang et al., 2019, 2018, Gao, 2010.

${ }^{22}$ Li et. al. (2020)

${ }^{23}$ Gao 2010, He, 2008

${ }^{24}$ Wang et al. (2014) 
with incentives to contribute. ${ }^{25}$ Thus, noncontributory social pensions have been adopted widely in countries with all levels of income. The experience with reducing old-age poverty is generally positive, although issues of fiscal sustainability have arisen in lower-income settings.

While non-contributary social pensions are proving to be an increasingly popular method for bridging the old-age coverage gap in pension systems, ${ }^{26}$ the current Chinese pension policy is still largely a "Bismarckian model" (contributions are required for pension entitlement). Despite of the tremendous expansion of URRPS, unless the benefit level meets some standard of adequacy, high coverage is not very meaningful. There have been several upwards adjustments of the basic pension in URRPS since 2014, the absolute level is still extremely low. In 2019, the level of basic pension is between 100 to 200 RMB per person per month in most of the provinces ${ }^{27}$, which is much lower than the level of Dibao (subsistence allowance) and the World Bank poverty line, both of which are around 400 RMB per person per month in 2019. On the other side, the fiscal sustainability of social pension is a key parameter for policy design. Lu et al. (2014) estimates the fiscal cost of a universal social pension scheme. They show that when setting the poverty line (6.6\% of GDP per capital, 2300 RMB in 2011) as the standard for pension benefit and increase retirement age to 65 , under moderate fertility rate, social pension would cost in total between 0.7 to $1 \%$ of GDP over the period to 2050. To put this into perspective, in 2019 the expenditure of BOAI accounts for about 5\% of GDP, while the expenditure of URRPS accounts for about $0.3 \%$ of GDP (Figure 6). Such estimation shows that it is reasonably achievable for China to establish a non-contributory social pension, which will keep most of the low-income aged people out of poverty.

Apart from the social pension, a further consideration for a pension system reform is the future integration of urban and rural pension systems - pooling all Chinese workers and retirees into a system with common rules, which implies full equalization of benefits between rural and urban areas. Literature on this topic is still very limited. Song et al. $(2012,2015)$ analyzes intergenerational redistribution in emerging economies with the aid of an overlapping generations model with endogenous labor supply. The model is used to analyze the welfare effects of alternative pension reforms in China. It shows that under reasonable assumptions, the additional fiscal imbalance for building universal pension system is small; In the reform, the welfare loss for urban employees (covered by BOAI) is very limited, while the welfare gains for urban and rural residents (who are not covered by BOAI) are substantial. Although

\footnotetext{
${ }^{25}$ Cai et al, 2012

${ }^{26}$ See Holzmann, Robalino, and Takayama (2009).

${ }^{27}$ Basic pension level in Shanghai, Beijing and Tianjin is higher than 200 RMB per person per month.
} 
the calibration shows that transfers to the rural sector are relatively inexpensive it is important to note that the calculations ignore any cost of administering and enforcing the system. In particular, the benefit would decrease if the enforcement of the social security tax in rural areas proves to be more difficult than in urban areas.

\section{China's public pension system is (still) not sustainable}

Another driving force for further reform is the concern of the fiscal sustainability of the current public pension system. Shifting demographics are creating major concerns about the long-term financial sustainability of old-age pension schemes all around the world. These concerns are particularly pressing in China due to a rapidly aging population.

\section{The challenge}

Findings from the existing research literature are largely consistent: without a reform, the current public pension system in China is not sustainable in the long run. ${ }^{28}$ Data from population projection shows that the share of the Chinese population over 65 years of age will double between 2010 and 2030. As shown in Figure 5, dependence ratio ${ }^{29}$ of BOAI raised from $19 \%$ to $39 \%$ in the last 30 years. Based on the latest pension report by Chinese Academy of Social Sciences (CASS) ${ }^{30}$, the dependence ratio will further rise to $60 \%$ in 2035 , and reach to $81.8 \%$ in 2050 . The evolution of dependence ratio in URRPS is even less optimistic, with similar increasing speed but at a higher level, it reaches $43 \%$ in 2019.

Because of the deteriorating aging trend in China, the public pension fund will reach to its limit in the very near future. Although the income of BOAI funds is larger than its expenditure for most of the years since 1989 (Figure 6), based on the estimation from CASS pension report, such trend will arrive at the turning point imminently, the accumulated balance of BOAI funds will soon reach to the peak in 2028 (around $4.5 \%$ of GDP) and then decreases, by 2035 it will be exhausted.

It worth to stress that under the current system, fiscal subsidies account for a substantial part to the BOAI fund income, for example in 2016 the total amount of fiscal subsidies is $0.9 \%$ of GDP, which

${ }^{28}$ see, e.g., Sin, 2005; Dunaway and Arora ,2007; Salditt, Whiteford, and Adema, 2007; Song et al., 2012, 2015; Williamson et al., 2017; Zhao and Mi, 2019; Zheng et al. 2019; Sun et al. 2020.

${ }^{29}$ Pension recipient/ pension contributors

${ }^{30}$ China Pension Actuarial Report 2019 -2050 
accounts for $19 \%$ of total BOAI fund income and (Figure 7). When excluding fiscal subsidies, BOAI funds began to run a current deficit already since 2015 and the accumulated balance will deteriorate even faster. The funds' situation in URRPS is equally severe, although much smaller than BOAI funds (Figure 8), it is heavily funded by the government. In 2018, 72\% of the fund's income is fiscal subsidies, only $23 \%$ is from the contribution. Based on the estimation from Sun et al. (2020), even with the government fiscal subsidies, the URRPS fund will begin to run a current deficit in 2020, despite of the positive accumulated balance in the early stage, the fund will be exhausted between 2035 and 2040.

Figure 5. Dependency ratio of China's pension system (\%)

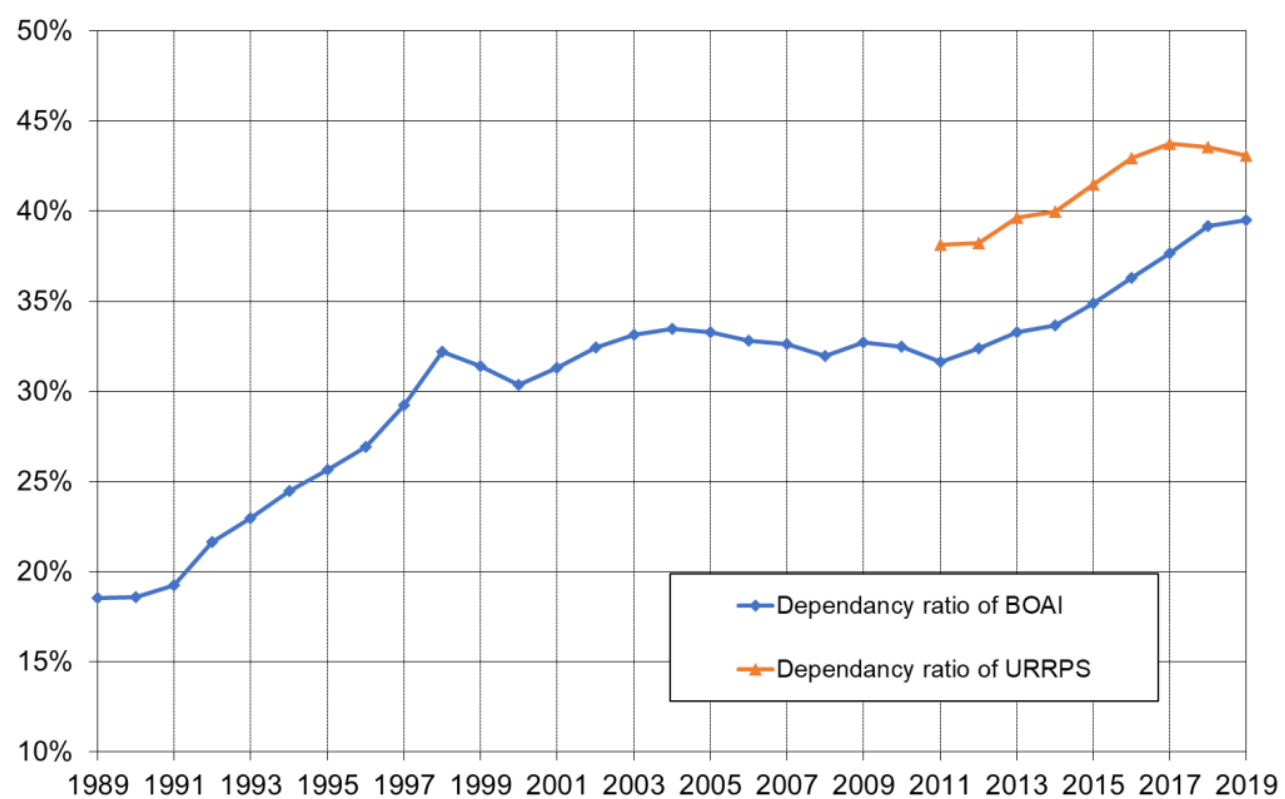

Notes: Dependency ratio is equal to the number of pension recipients divided by the number of pension contributors. Statistics are estimated based on data published by National Bureau of Statistics of China (http://www.stats.gov.cn/tjsj/).

Figure 6. Income and expenditure of China's pension system (\% of GDP) 


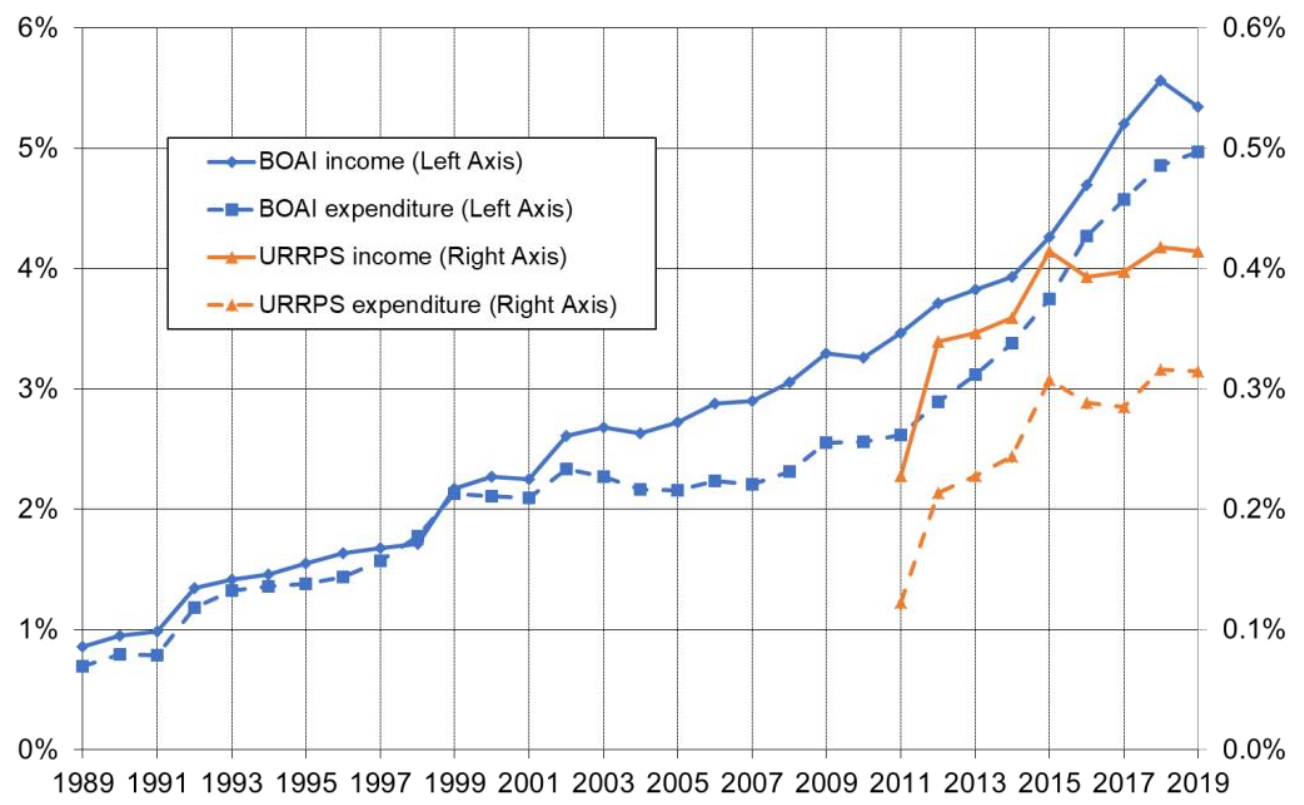

Notes: Statistics are estimated based on data published by National Bureau of Statistics of China (http://www.stats.gov.cn/tisi)).

Figure 7. Source of the BOAI Funds (\%)

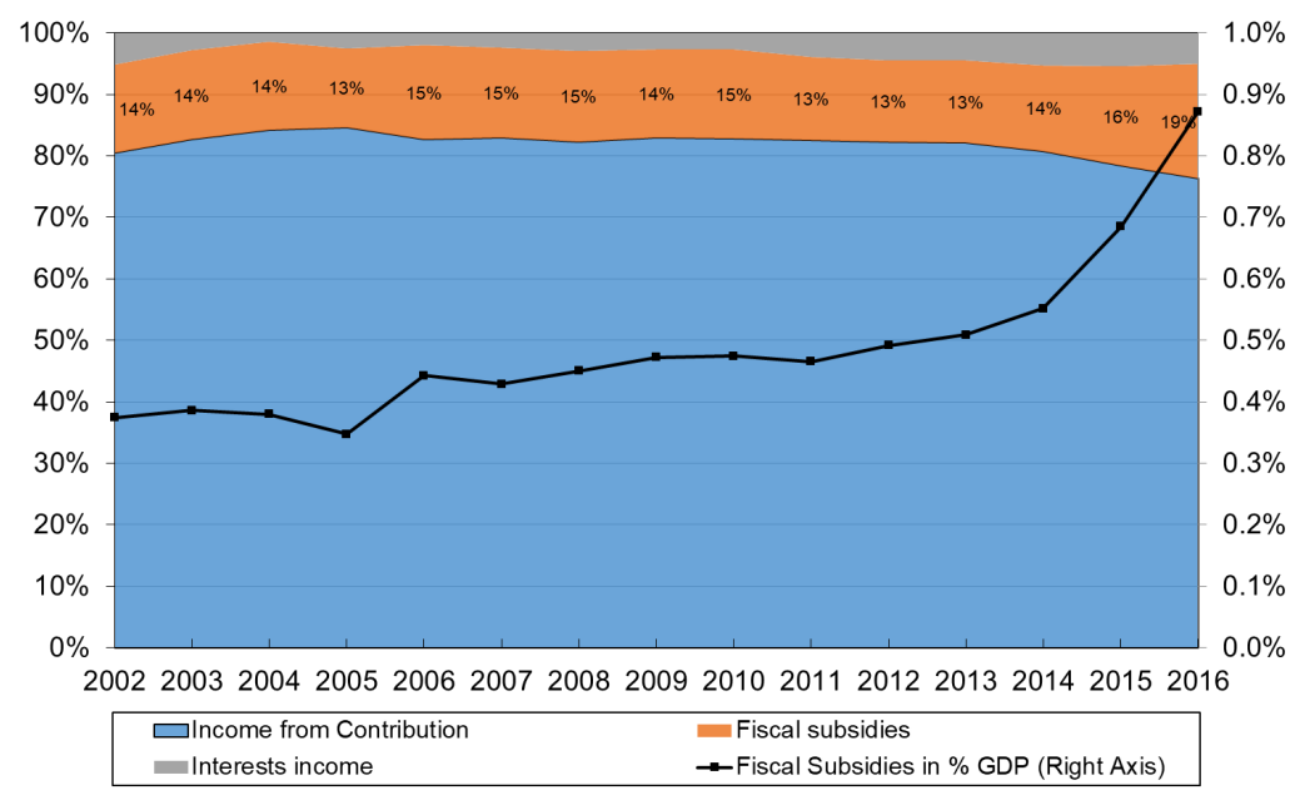

Notes: Statistics are estimated based on data published by Finance Year Book of China $(2018,2019)$ and Sun $(2017)$.

Figure 8. Source of the URRPS Funds (\%) 


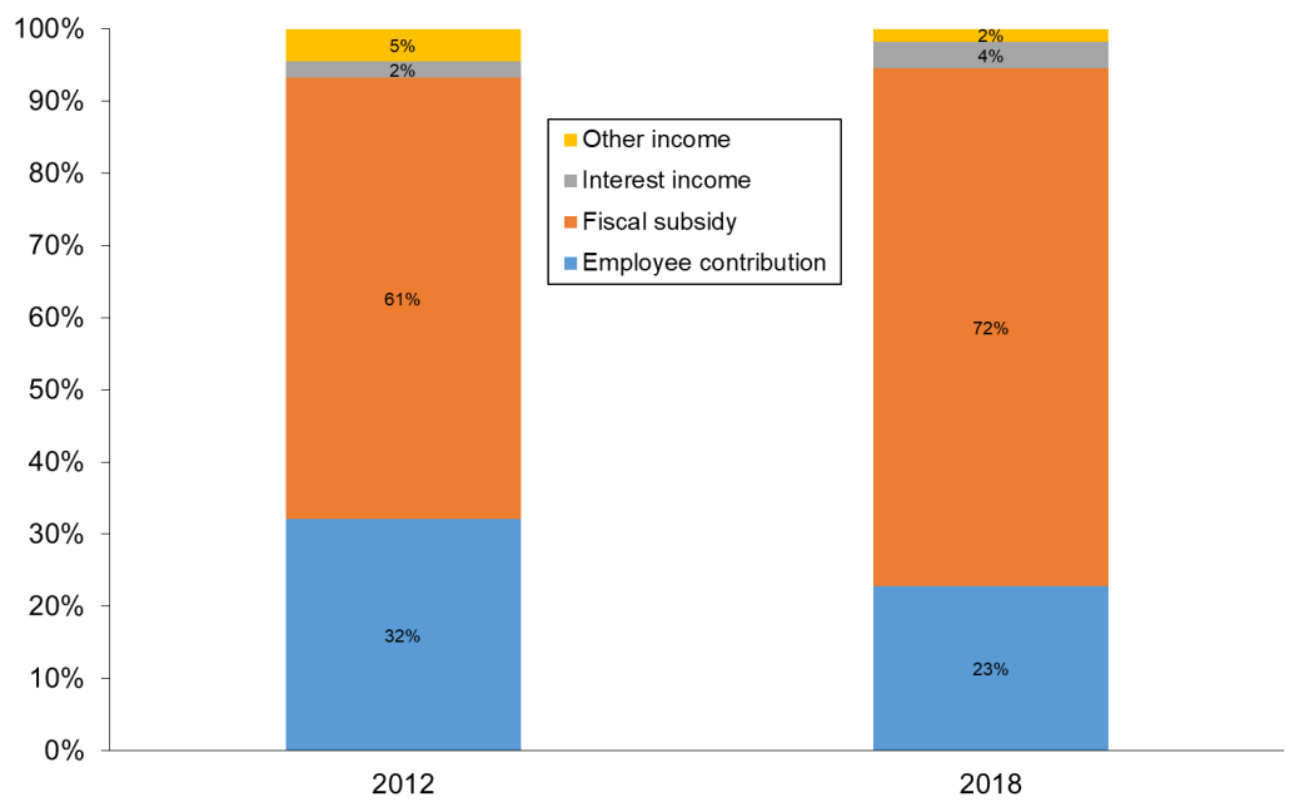

Notes: Statistics are estimated based on data published by Finance Year Book of China (2017, 2018) and Sun (2017).

Possible solutions: extending retirement age, injecting state capital, land compensation schemes, social pensions

Multiple reform options have been discussed among researchers as well as policy makers, some of which has already been piloted in the national level or regional level, including extending the retirement age, injecting state capital into the social security fund and land compensation schemes for farmers.

China is among the countries with the lowest retirement age in the world (Figure 9). Extending the legal retirement age is naturally one of the key policy measures to help the system achieve long run sustainability. Based on Song et al. (2012), given the current social security tax and replacement ratio in BOAI, increasing retirement age by six years ${ }^{31}$ would not only permanently restore financial sustainability, but also generate large welfare gain. Zhao et al. (2019) estimate the impact of rising retirement age by 1 year in 2030 and a further 1-year extension in 2040 in BOAI, under such reform the pension gap ${ }^{32}$ will reduce for all the years from 2020 to 2070, in particularly, the annual pension gap will be reduced by around $8 \%$ and $27.8 \%$ in 2050 and 2070 respectively. However, the policy is always challenged with political barriers, such as strikes and social anxiety.

\footnotetext{
${ }^{31}$ i.e., retirement age would have to increase from 60 to 66 years without any reduction in employment

${ }^{32}$ Pension gap is defined as pension income minus pension expenditure.
} 
In the case of China, the idea of gradually delaying retirement age has entered the government agenda in recent years but previous attempts collapsed because of enormous pressure from the public and social media. The government has now launched a new attempt to push revenant reform forwards. The recent Five-Year Plan (2021-2025) published in March 2020 explicitly states the implement of progressive extension of the statutory retirement age. ${ }^{33}$ The Ministry of Human Resources and Social Security (MHRSS) is in charge of implementing the reform. In the recent State Council Information Office press conference held on February $26^{\text {th }}$ 2021, the vice Ministry of MHRSS announced that MHRSS is currently cooperating with other official entities to lay down the detailed reform plan.

Figure 9. Retirement Age

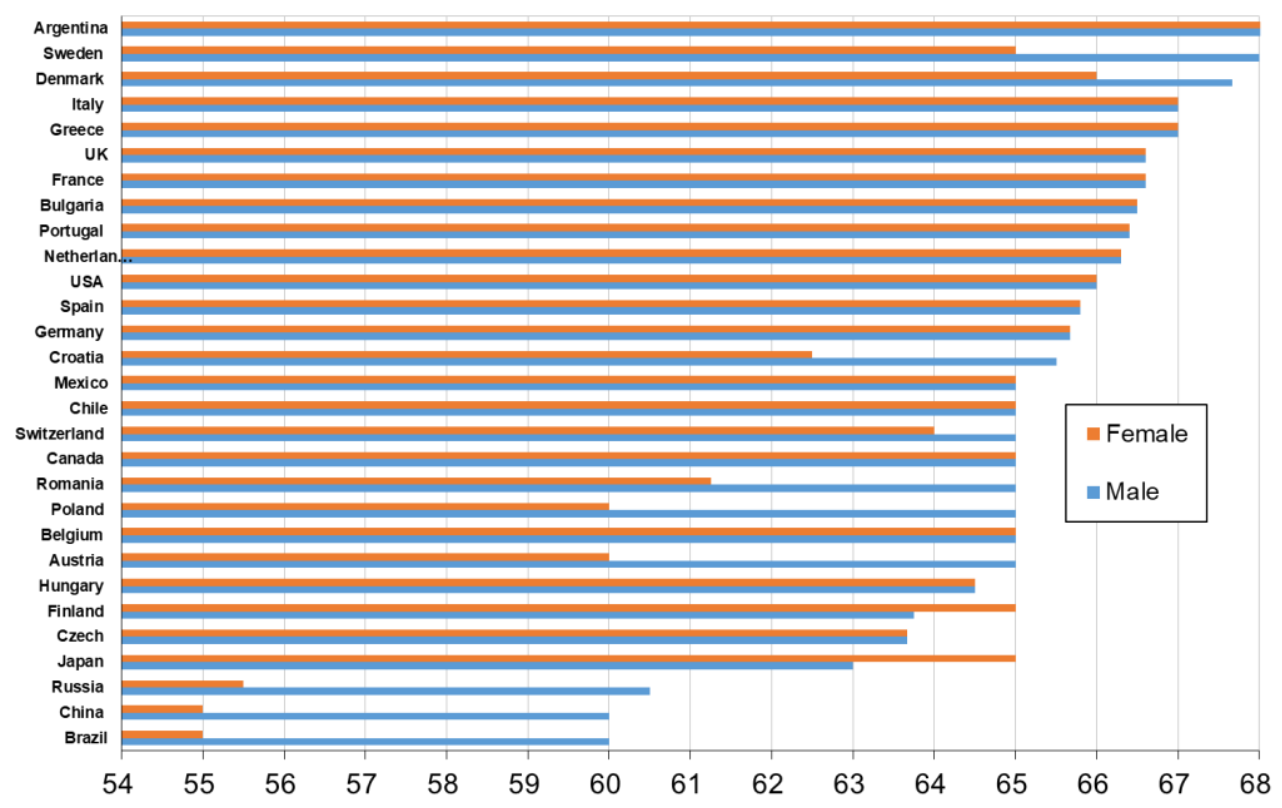

Notes: Data from Finnish Center for Pension (https://www.etk.fi/en/work-and-pensions-abroad/international-comparisons/retirement-ages/) and Williamson et al. (2017).

Besides extending the retirement age, another ongoing trial responding to the increasing balance pressure of the public pension funds is to transfer part of state capital into social security fund. The plan was initiated in $2001^{34}$, since when $10 \%$ income from the initial public offer (IPO) or the secondary public offering (SPO) of state-owned companies would need to be transferred to newly established

\footnotetext{
${ }^{33}$ the Fourteenth Five-Year Plan for National Economic and Social Development and the Long-term Goals for 2035 (http://www.xinhuanet.com/2021-03/13/c_1127205564_9.htm)

${ }^{34}$ See "Interim Measures of the State Council on the Management of Reducing Held State Shares and Raising Social Security Funds", State Council Document [2001] 22
} 
National Social Security Fund (NSSF, in Chinese: 全国社会保障基金 ). ${ }^{35}$ In 2009, the measures extend to all the joint stock limited company with state-owned shares, while $10 \%$ of the actual number of the IPO stocks, instead of income, would need to be transferred to NSSF. ${ }^{36}$ In 2017 , the measures further extend to all the medium and large-sized local and central state-owned and state-controlled enterprises and financial institutions (listed or unlisted), who would need to transfer 10\% share of the enterprises to NSSF or other provincial level social security fund management entities before December $2020 .{ }^{37}$

As nominal shareholder, NSSF and other fund management entities have the right to share dividends from the enterprise, however whether they should also have the full disposal of the shares is still under the discussion among the policy makers. Based on the 2019 national assets report by the State Council ${ }^{38}$, the net wealth of state owned financial and non-financial enterprise is 85 trillion RMB (about $86 \%$ of 2019 GDP), which means in total there will be 8.5 trillion RMB assets transferred to social security fund. Assuming the dividend yield of the State-owned Enterprise (SOE) is $1.64 \%^{39}$ in 2019, then the total dividend income from the transferred shares will be 155.8 billion RMB, which accounts for only $3.2 \%$ of OBAI expenditure, but $50 \%$ of URRPS expenditure in 2019. It is reasonable to assume that the return of the transferred assets will increase if NSSF and other fund management entities are entitled to the full disposal of the shares (i.e. selling or transferring the shares or using the shares as collateral for loans). In any case, in the foreseeable future, state capital will play an important yet supplementary role to help the public pension achieve long run sustainability

Another unique China-specific polit program for improving rural pension provision is to compensate farmers with social insurance (pension and medical insurance) for land acquisition. The method was first adopted in Jiaxing (Zhejiang Province) in early 1990s, instead of paying the farmers with one-time compensation for land acquisition, the local government pay for social insurance and monthly subsidies

\footnotetext{
${ }^{35}$ Note that National Social Security Fund is different from the current account of social security fund. NSSF serves as a strategic reserve fund accumulated by the central government to support future social security expenditures and other social security needs.

${ }^{36}$ See "Notice of the Ministry of Finance, State-owned Assets Supervision and Administration Commission, China Securities Regulatory Commission and National Council for Social Security Fund about Issuing the Implementing Measures for the Transfer of Some State-owned Shares from the Domestic Securities Market to the National Social Security Fund", Ministry of Finance [2009] 94

${ }^{37}$ See "Notice of the Ministry of Finance, State-owned Assets Supervision and Administration Commission, China Securities Regulatory Commission and National Council for Social Security Fund about Issuing the Implementing Measures for the Transfer of Some State-owned Shares from the Domestic Securities Market to the National Social Security Fund", Ministry of Finance [2009] 94

${ }^{38} \mathrm{http} / / / w w w . n p c . g o v . c n / n p c / c 30834 / 202010 / 8459210 b 544 \mathrm{e} 4 b 9 \mathrm{dba} 931 \mathrm{e} 5 \mathrm{~b} 4682 \mathrm{e} 9 \mathrm{fa} . \mathrm{shtml}$

${ }^{39}$ Based on the 2019 report from China Security Index Cooperation. http://www.csindex.com.cn/uploads/researches/files/zh_CN/research_c_1622.pdf
} 
for the losing-land-farmers. Such method was later popularized in other regions with variations. In 2006, the State Council stipulated that local government are not allowed to expropriate the land without providing social insurance to the affected farmers ${ }^{40}$, which was written into the new Land Management Law in 2020. By 2015, there are 30 million losing-land-farmers were covered by the social security system (Liao, 2015). Despite of the strong policy support from the central government, the method is still highly controversial till today. Indeed, social insurance will, in theory, provide support for the longterm livelihoods of the losing-land-farmers, in reality inadequate compensation, forced eviction, and land-related corruption prevail in China, causing numerous rural protests against land expropriation. ${ }^{41}$ Unequivocally the method of financing the social insurance with land compensation will help to address the public pension fund pressure for the rural residents, since the program is implemented with different policies across regions, so far there is no research to estimate to what extent such program would contribute to the sustainability of the public pension in the national level.

Besides extending the retirement age and increase public income with various means, establishing a social pension system, which will improve the distributive function of pension, is also proposed by researchers as a cure for restore the financial sustainability of public pension system. For example, in the pension report by $\mathrm{CASS}^{42}$, the authors propose to transform the current two tiers public system (social pooling and individual pension account) into social pension and individual pension account, where the social pension part equal among all the participants, providing the basic support for living, while the personal account pension functions as pension saving vehicle, which will become the main part of pension income. Although the estimated transition cost is low, since such reform requires a change of the entire structure of the existing pension system, it is still not yet under the consideration of the policy makers.

\section{Conclusion: sustainability vs. equity}

China's public pension reforms have come a long way. Especially since the $11^{\text {th }}$ Five-Year Plan (20062010), reforms have accelerated. Until today, the Chinese government has made tremendous achievement in term of expending pension coverage and rising benefits comparing to the beginning of the century. Yet, there are increasing urgence for further reforming the system to improve inequality

\footnotetext{
40 "Notice of the State Council on Relevant Issues Concerning Strengthening Land Regulation", State Council Document [2006] 31

${ }^{41}$ Cai (2015)

${ }^{42}$ China Pension Actuarial Report 2019 -2050
} 
and long-term sustainability of the public pension. In the latest Five-Year Plan (2021-2015), the government has vowed to construct a unified, equitable, and sustainable pension system with full coverage. Given the impressive track record in the past decade, it is reasonable to assume that in the coming five years the Chinese government will continue pushing hard on expanding the coverage and improving sustainability of the pension system (e.g., increase retirement age). Hereby, addressing the sustainability of BOAI seems to be the priority focus of the government. The basic pension level in URRPS will continue rising, but it is unlikely that the huge existing gap of pension benefit between BOAI and URRPS (about 20 times) will significantly decrease in the next five year. Despite of the evidence from the exciting research that the transition cost to build non-contributory social pensions or implement an integration of urban-rural pension systems is moderate, such plan has not yet entered the government's consideration.

\section{Reference}

Baeten, S., Van Ourti, T., \& van Doorslaer, E. (2013). Rising inequalities in income and health in China: Who is left behind? Journal of Health Economics, 32(6), 1214-1229.

Cai, F., Giles, J., O'Keefe, P., \& Wang, D. (2012). The Elderly and Old Age Support in Rural China. The Elderly and Old Age Support in Rural China. The World Bank.

Cai, Meina. (2016). Land for welfare in China. Land Use Policy, 55, 1-12.

Cai, Meng, \& Yue, X. (2020). The redistributive role of government social security transfers on inequality in China. China Economic Review, 62, 101512.

China Development Research Foundation (中国发展研究基金会). (2020). Aging Population: China's Development Trends and Policy Options (中国发展报告2020：中国人口老龄化的发展 趋势和政策). Beijing: China Development Press (中国发展出版社).

Dunaway, S. V., \& Arora, V. B. (2007). Pension Reform in China: The Need for a New Approach. IMF Working Papers, 07(109), 1.

Fu, D. (Ed.). (2018). Finance Yearbook of China. Beijing: Zhong Guo Cai Zheng Za Zhi She.

Fu, D. (Ed.). (2019). Finance Yearbook of China. Beijing: Zhong Guo Cai Zheng Za Zhi She.

Gao, Q. (2010). Redistributive nature of the Chinese social benefit system: Progressive or regressive? 
China Quarterly, 201(201), 1-19.

He, L. (2008). The distributional effects of public pension reform in urban China. Frontiers of Economics in China, 3(2), 255-276.

Holzmann, R., Robalino, D., \& Takayama, N. (2009). Closing the coverage gap: role of social pensions and other retirement income transfers (Book, 2009). Washington, DC: World Bank.

Hu, W. (2019). A Stock Market Dividends Report. Beijing.

Leung, J., \& Nann, R. (1995). Authority and Benevolence. Social Welfare in China. New York: St. Martin's.

Li, J., Wang, X., Xu, J., \& Yuan, C. (2020). The role of public pensions in income inequality among elderly households in China 1988-2013. China Economic Review, 61, 101422.

Liao, H. (2015). Risk Control of Chinese Rural Land Transfer (农村土地流转风险控制研究). Beijing: social science academic press.

Lu, Q., \& Stepan, M. (2016). The Establishment of China's New Type Rural Social Insurance Pension: A Process Perspective. Journal of Current Chinese Affairs, 45(2), 113-147.

Salditt, F., Whiteford, P., \& Adema, W. (2007). Pension Reform in China: Progress and Prospects. OECD Social, Employment and Migration Working Papers, 53. Retrieved from

Shen, K., Feng, W., \& Cai, Y. (2018). A Benevolent State Against an Unjust Society? Inequalities in Public Transfers in China. Chinese Sociological Review, 50(2), 137-162.

Sin, Y., \& Yu, X. (2005). China - pension liabilities and reform options for old age insurance. Economics.

Song, Z. M., Storesletten, K., Wang, Y., \& Zilibotti, F. (2012). Sharing High Growth across Generations: Pensions and Demographic Transition in China. UBS Center Working Paper Series , November(1).

Song, Z., Storesletten, K., Wang, Y., \& Zilibotti, F. (2015). Sharing High Growth across Generations: Pensions and Demographic Transition in China. American Economic Journal: Macroeconomics, 7(2), 1-39.

Sun, L., Su, C., \& Xian, X. (2020). Assessing the Sustainability of China's Basic Pension Funding for 
Urban and Rural Residents. Sustainability, 12(7), 1-17. Retrieved from

Sun, Y. (2017). Y. Evaluation and prospect on China's basic pension fund since 2010. In B Zheng (Ed.), China Pension Report 2017 (p. P23). Beijing: Economy and Management Press.

Wang, F., Shen, K., \& Cai, Y. (2019). Expansion of public transfers in China: Who are the beneficiaries? Journal of the Economics of Ageing, 14. https://doi.org/10.1016/j.jeoa.2019.100194

Wang, L., Béland, D., \& Zhang, S. (2014). Pension fairness in China. China Economic Review, 28, $25-36$.

Williamson, J. B., Fang, L., \& Calvo, E. (2017). Rural pension reform in China: A critical analysis. Journal of Aging Studies, 41, 67-74.

Zhao, Q., \& Mi, H. (2019). Evaluation on the Sustainability of Urban Public Pension System in China. Sustainability, 11(5), 1-20.

Zheng, Bingwen et al. (2019). China Pension Actuarial Report 2019 -2050 (中国养老金精算报告20192050). Beijing: China Social Security Press (中国劳动社会保障出版社). 